
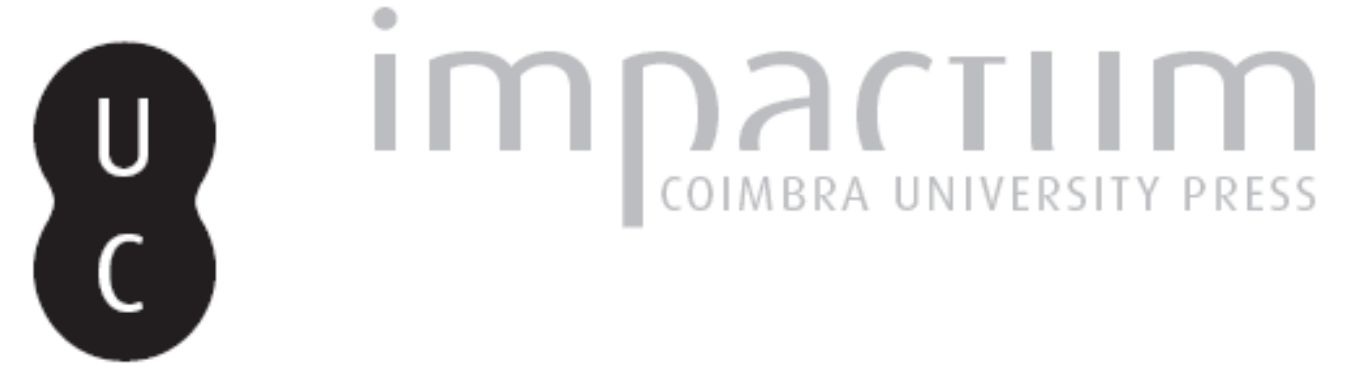

\title{
O mosteiro de Lorvão: ainda a saída dos monges e a entrada das freiras
}

Autor(es): $\quad$ Marques, Maria Alegria Fernandes

Publicado por: Centro de História da Sociedade e da Cultura

URL persistente:

URI:http://hdl.handle.net/10316.2/39477

DOI:

DOI:http://dx.doi.org/10.14195/1645-2259_11_3

Accessed : $\quad$ 26-Apr-2023 12:48:36

A navegação consulta e descarregamento dos títulos inseridos nas Bibliotecas Digitais UC Digitalis, UC Pombalina e UC Impactum, pressupõem a aceitação plena e sem reservas dos Termos e Condições de Uso destas Bibliotecas Digitais, disponíveis em https://digitalis.uc.pt/pt-pt/termos.

Conforme exposto nos referidos Termos e Condições de Uso, o descarregamento de títulos de acesso restrito requer uma licença válida de autorização devendo o utilizador aceder ao(s) documento(s) a partir de um endereço de IP da instituição detentora da supramencionada licença.

Ao utilizador é apenas permitido o descarregamento para uso pessoal, pelo que o emprego do(s) título(s) descarregado(s) para outro fim, designadamente comercial, carece de autorização do respetivo autor ou editor da obra.

Na medida em que todas as obras da UC Digitalis se encontram protegidas pelo Código do Direito de Autor e Direitos Conexos e demais legislação aplicável, toda a cópia, parcial ou total, deste documento, nos casos em que é legalmente admitida, deverá conter ou fazer-se acompanhar por este aviso.

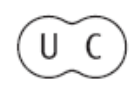




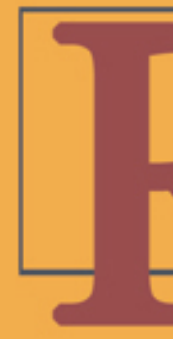

\section{evista de História} da Sociedade e da Cultura

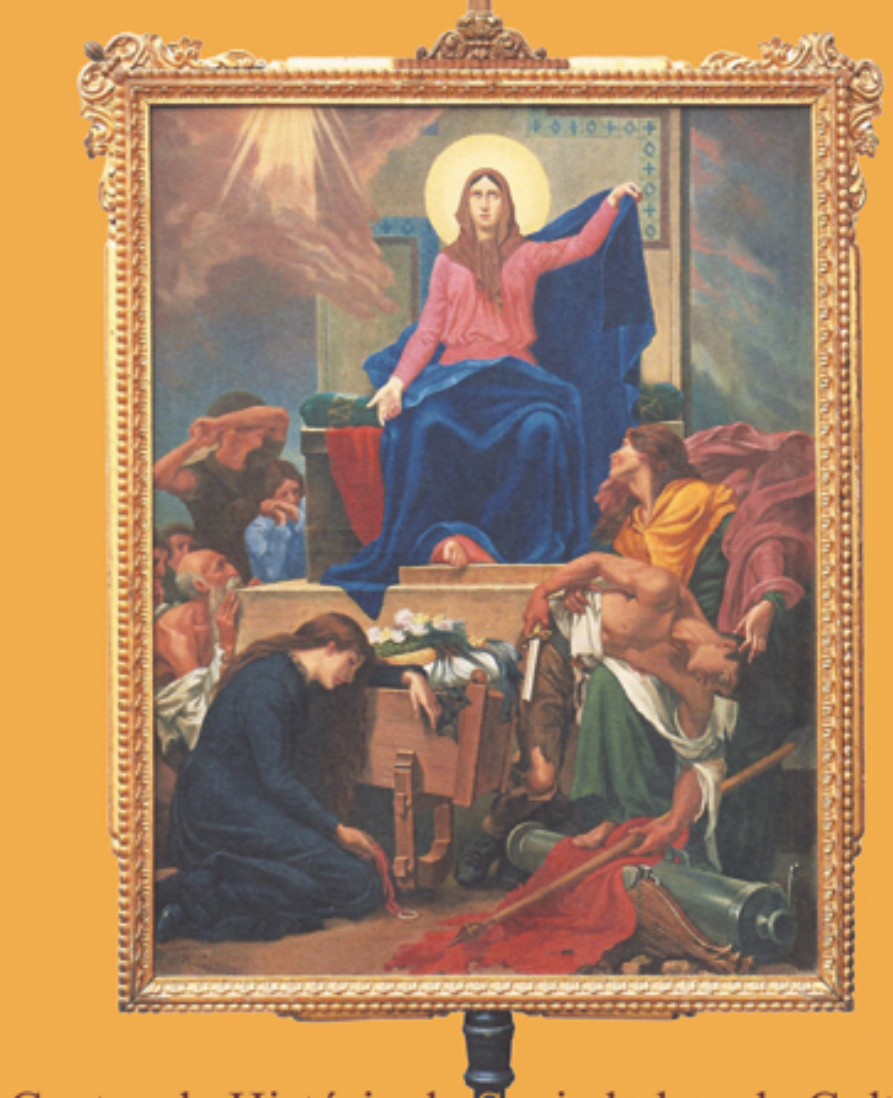

Centro de História da Sociedade e da Cultura Universidade de Coimbra 


\title{
O mosteiro de Lorvão: ainda a saída dos monges e a entrada das freiras*
}

\author{
Maria Alegria Fernandes Marques \\ Faculdade de Letras \\ Centro de História da Sociedade e da Cultura \\ Universidade de Coimbra \\ alegriamarques@sapo.pt
}

Texto recebido em/ Text submitted on: 27/02/2011

Texto aprovado em/ Text approved on: 27/06/2011

Resumo/Abstract:

Neste trabalho retoma-se uma temática antiga, a passagem do mosteiro de Lorvão de comunidade masculina a casa monástica feminina, sob a égide de $\mathrm{D}$. Teresa, filha do segundo rei de Portugal e ex-rainha de Leão, numa leitura e numa crítica mais aprofundada dos documentos.

By a new approach and a deeper review of the documents, this paper gets back to an old subject: the replacement in the monastery of Lorvão of a masculine community by a feminine monastic house, supported by D. Teresa, daughter of the second portuguese king and ex-queen of Lion.

Palavras chave/Keywords:

Mosteiro de Lorvão; Beneditinos; Cistercienses; Rainha D. Teresa Sanches.

Monastery of Lorvão; Benedictines; Cistercians; queen D. Teresa Sanches.

* Seminário Dos Monges de São Mamede às Monjas de Santa Maria do Lorvão Continuidades e rupturas na cultura unducentista do Mosteiro Laurbanense. Lisboa-FCSH - UNL, IEM., 25.03.10. 
1. Há oito séculos, vivia-se ainda a contenda entre monges do mosteiro de Lorvão e as monjas que a rainha D. Teresa ${ }^{1}$, infanta de Portugal, fizera nele introduzir. Iniciada no início do séc. XIII, no meio de grande celeuma e discórdia, de processos mais ou menos dúbios, pelo menos por parte do bispo de Coimbra, do rei de Portugal, D. Sancho I, e de uma facção dos seus monges, tal contenda permitiria a entrada de monjas talvez pelo Natal de 1205.

Esta acontecia após renúncia dos monges ao seu mosteiro secular. As freiras faziam a sua entrada segundo a regra de S. Bento. Porém, este não seria o fim do processo, por qualquer óptica que o encaremos. Não o seria quanto ao facto, nem quanto ao direito. Tanto que, por queixas e reclamações da parte do mosteiro não conivente com as acções que haviam determinado a saída, junto da Santa Sé, o papa haveria de ver-se obrigado a decidir a partida das freiras e a ordenar a reentrada dos monges, bem como as monjas haveriam de transmudar a sua obediência da regra de $\mathrm{S}$. Bento à observância cisterciense.

O processo só conheceria o seu epílogo durante a primeira metade do ano de 1211, quando o bispo de Lamego, por comissão do arcebispo de Compostela, deu execução à bula Causa que vertebatur, de Inocêncio III, passada em Latrão, em Novembro de $1210^{2}$. Se o papa tinha determinado a saída das monjas e o reingresso dos monges, com a sua reinstalação nas suas dignidades e ofícios, como cada um ocupava antes da entrada da comunidade feminina, o que é facto é que nem tudo correu como o enunciado no documento papal, pois que os monges se recusaram a essa quase encenação e renunciaram ao seu mosteiro. Além de decidir a substituição momentânea da comunidade, o documento papal exigia também a presença de um guardião, que garantisse a fidelidade do processo, bem como mandava que os monges liquidassem qualquer dívida que, eventualmente, a sua comunidade tivesse

1 Mais rigorosamente, ex-rainha de Leão, pois que fora casada com o rei Afonso IX, seu primo direito, parentesco que valera a dissolução do matrimónio, por ordem do papa Celestino III, em 1191. Em virtude dela, D. Teresa regressou a Portugal, trazendo consigo sua filha mais nova, a infanta D. Dulce.

2 Bulário Português. I. Inocêncio III (1198-1216). Ed. Avelino de Jesus da Costa e Maria Alegria Fernandes Marques. Coimbra, Centro de História da Sociedade e da Cultura, 1989, p. 286-287, n. ${ }^{\circ} 148$ (doravante, citaremos apenas por Bulário...). 
em aberto. Ressarcidos pela rainha D. Teresa das despesas do processo, haveriam então, de ser distribuídos «por mosteiros bem ordenados».

Seguidos os trâmites, com a excepção da reentrada dos monges, ficava legalizado desta forma, todo o processo de saída da comunidade masculina do mosteiro de Lorvão. Então, seria oportunidade para a entrada da congregação feminina, (cujo número poderia atingir as 40 freiras) que, doravante, viveria segundo os estatutos da ordem de Cister.

2. A renúncia dos monges não foi processo fácil, nem, por isso mesmo, se esgotou no momento. O mosteiro, habitado durante séculos por monges que, cremos, haviam abraçado a regra de $\mathrm{S}$. Bento ${ }^{3}$, guardava a memória de que fora protegido de reis e das famílias da mais alta nobreza do antigo reino da Galiza. Como ficou sinal na lenda do abade João, recordava que fora reduto do Cristianismo contra as investidas dos muçulmanos ${ }^{4}$. Como bem comprovavam os seus vastos domínios, alguns coutados de tempos imemoriais, o mosteiro recordava que tomara a seu cuidado o povoamento e o desenvolvimento de tantas zonas do território que os esforços militares cristãos iam ganhando para a Cristandade. E afirmara-se ainda como centro irradiador de cultura, como o atestavam as belíssimas obras nele produzidas - Apocalipse e Livro das Aves, para só mencionarmos as mais conhecidas e as mais emblemáticas -, e que os monges ciosamente

3 Assim tem sido entendimento, nosso também. Cfr. Maria Alegria Fernandes Marques, "Inocêncio III e a passagem do mosteiro de Lorvão para a Ordem de Cister", in Estudos sobre a Ordem de Cister em Portugal. Lisboa, Edições Colibri - Faculdade de Letras da Universidade de Coimbra, 1998, p. 75 (doravante, citaremos apenas por Estudos..); Nelson Correia Borges, Arte monástica em Lorvão. Sombras e realidade. I. Das origens a 1737. I, Lisboa: Fundação Calouste Gulbenkian / Fundação para a Ciência e a Tecnologia, 2001, p. 82. Notamos, todavia, que, em trabalho recente, Aires Nascimento propõe outra visão, bem diferente, do problema; cfr. Mosteiro de Lorvão: a história possível dos seus tempos antigos», in Liber Testamentorum coenobii Laurbanensis (Estudios). Colección «Fuentes y Estudios de Historia Leonesa», n. ${ }^{\circ}$ 125. León: Centro de Estudios e Investigaciones «San Isidoro». Caja España de Inversiones / Archivo Histórico Diocesano, 2008, p. 102-107, chegando mesmo a colocar a hipótese de ter sido "a defesa das suas tradições" a levar "à extinção definitiva da comunidade rebelde em inícios do século XIII". O mesmo autor considera as várias referências à regra de $\mathrm{S}$. Bento como "um registo de padrão consagrado" (p. 103).

4 De reter que Aires Nascimento propôs que essa lenda tivesse tido origem no séc. XII, colocando em relevo um antigo abade do mosteiro, ainda que lendário, e a sua acção nestes confins da Cristandade; cfr. ob. cit., p. 155. 
guardavam. Era este mosteiro que, nesse início do séc. XIII, se via envolto num processo de difamação e perseguição que tempo nenhum fazia prever, nem acção se conhece que tal pudesse justificar.

Como é sobejamente conhecido, os argumentos que, na ocasião, foram apresentados para justificar a actuação do poder eclesiástico e do político, faziam recair sobre os monges o ónus de tal decisão. (...) "vida dissoluta (...) e delapidação e destruição do seu mosteiro e das suas coisas" foram as razões que o bispo de Coimbra, D. Pedro Soares, deixou que fossem escritas acerca da mais antiga comunidade monástica da sua diocese ${ }^{5}$. Se tinha ou não consciência de que tais argumentos poderiam ultrapassar séculos e fazer doutrina, nunca o poderemos saber. Ao contrário, já poderemos, e creio que deveremos, procurar um amplo espectro documental para aferir acerca do valor desse argumento. E aqui, pessoalmente, com os meus estudos (e seja-me permitido recordá-lo) creio ter contribuído para aquilo que considero a reabilitação da memória dos monges desse mosteiro $^{6}$. Por isso, não voltarei ao tema. Como não revisitarei a questão da entrada das monjas, o papel de D. Teresa, o tema das suas companheiras.

3. No entanto, regresso ao tema da saída dos monges. Ainda que distanciada do objecto de estudo, há questões que nos tocam mais e que recorrentemente nos visitam. Para mim, esta é uma delas: como pôde terminar, por tal processo, um longo e brilhante período de vida de uma instituição? Mas, ainda hoje, trago mais questões que respostas.

Em primeiro: saídos no final do ano de 1205 do mosteiro de Lorvão, que foi feito dos monges seus habitantes? Para onde foram? Que destino tiveram? E este foi gizado em percurso individual ou colectivo?

Recordemos, a este propósito, alguns elementos: em 1211, Inocêncio III considerava que o mosteiro tinha capacidade para acolher 40 monjas ${ }^{7}$. Seria esse o número de monges? Aires Nascimento, nas páginas que subscreve no excelente estudo que acompanha a belíssima edição do

5 Ou pelo menos dentre aquelas de que há mais notícias e de que se pode conhecer a sua história.

6 Maria Alegria Fernandes Marques, Estudos..., p. 75-125.

7 Bula Causam que vertebatur, de 1210 Novembro 15, Latrão, dirigida ao arcebispo de Compostela. Bulário..., p. 286-287, n. ${ }^{\circ} 148$. 
Livro dos Testamentos de Lorvão, indica que o mosteiro albergaria cerca de 16 monges, ainda que admita que esse número poderá ser algo alargado em função do proposto pelo papa ${ }^{8}$.

Esta diferença de número acaso justifica a acusação de vida dissoluta apontada pelo bispo de Coimbra? Isto é, a admitir-se a boa informação do papa, a sua indicação tem de ser tida como credível. Logo, contrapor-se-lhe uma comunidade de monges de cerca de 16 membros, menos de metade daquela que o papa previa para monjas, parece indicar uma menor valorização da casa monástica, da sua imagem e do seu património, em tempo dos monges.

Notemos, porém, que a análise do processo mostra-nos como certa apenas uma fugidia presença e intervenção de monges do mosteiro, uns escassos seis (entre os quais apenas dois presbíteros) do grupo que podermos considerar pró-entrega do mosteiro ${ }^{9}$ e um solitário, mas apagado Fr. Estêvão, que, tendo comparecido perante os juízes apostólicos, o bispo e o deão de Zamora e o abade de Moreruela (após a entrada das monjas no mosteiro de Lorvão, isto é, pelo ano de 1207 ou primeira metade de $1208^{10}$ ), inquirido se pretendia alegar algo no processo, particularmente acerca do mandato papal de retirada das freiras do mosteiro e reentrada dos monges

8 Ob. cit., p. 113 e nota 89.

9 Aqueles que deixaram os seus nomes em documento que atesta a inexistência de violência sobre a comunidade, por parte do rei Sancho e de sua filha, bem como a concessão voluntária do seu mosteiro e a demarcação da acção que alguns outros moviam contra a rainha. Maria Alegria Marques, Estudos..., p. 107, doc. 10. Se assim era, sobretudo esta segunda situação, parece evidente que a comunidade lorbanense se achava dividida, agora, como já o estivera antes. E tanto mais nos inclinamos para esta interpretação quanto, aproximando a bula Si karissimus in Christo, de 24 de Outubro de 1206 e o documento em que vários monges de Lorvão declararam, perante o bispo e o deão do Porto, que não tinha sido exercida violência sobre eles pelo rei $\mathrm{D}$. Sancho nem por sua filha e que concederam voluntariamente o seu mosteiro (cfr. Estudos..., p. 106-107, docs. n. ${ }^{\circ} 9$ e 10, respectivamente), se conclui que estes documentos, contemporâneos, revelam atitudes e sentimentos bem diversos por parte de monges de Lorvão. E isso nos leva a crer numa dissensão na comunidade.

${ }^{10}$ Uma vez que o bispo de Zamora é comissionado por bula de 24 de Outubro de 1206 (Si karissimus in Christo; cfr. Estudos..., p. 106, n. ${ }^{\circ}$ 9) e a informação destas diligências se acha em documento de 30 de Julho de 1208 (ibidem, p. 108-111, n. ${ }^{\circ} 12$ ). 
(em $1206^{11}$ ), nada quis dizer, nem por si, nem pelos outros ${ }^{12}$. A esse reduzido grupo se juntava o seu abade, como é óbvio.

Regressando às nossas questões, cremos ser de admiti-las, dado o desenrolar do processo. A existência da apelação para o papa e a sustentação da questão, por parte de um grupo de monges, onde se encontrava o abade Julião, e que teve de ser protagonizada pelos descontentes ${ }^{13}$, são a prova da manutenção de um espírito senão de comunidade, pelo menos de grupo, da facção que aqueles formavam. Por outro lado, a sentença final de Inocêncio III, ao mandar retirar as monjas e fazer regressar os monges à sua casa, restituindo-lhes ofícios e dignidades, parece prever alguma facilidade em reagrupar os antigos (ou, pelo menos, a maior parte dos antigos) habitantes do mosteiro de Lorvão. Um vez que nos parece haver uma clara dissensão no mosteiro, não sabemos onde estariam todos os monges, pois pensamos que aquela se prolongaria na divisão da comunidade e afastamento dos grupos.

Porém, fica-nos certa a entrada do abade Julião e de alguns monges (cujos nomes nos ficam desconhecidos), no mosteiro de Pedroso, ou noutros ${ }^{14}$,

${ }^{11}$ A bula citada na nota anterior.

${ }^{12}$ Estudos..., p. 109, doc. 12. Convenhamos, porém, que, neste momento, ainda seria possível alguma união entre os monges: coniventes ou resistentes, ambos os grupos tinham uma razão para existir; uns, a exemplo do abade Julião, que mudou de campo ou, pelo menos, de ideias quanto ao mosteiro, pretendiam fazer reverter a situação, outros, pela natureza da sua posição no processo; todos em obediência ao mandato apostólico.

13 Já em Outubro de 1206 o papa declarava que os monges se lhe haviam queixado de que tinham sido expulsos violentamente, do seu mosteiro, pelo rei, para o conceder a sua filha Teresa (cfr. bula Si karissimus in Christo, de Latrão, Outubro, 24, in Estudos..., p. 106, doc. 9). Já aí se lê que o abade resignara o mosteiro nas mãos do rei sem o consenso e vontade do seu convento. No entanto, a referência a uma atitude de revolta do abade Julião perante a nova ordem das coisas apenas se acha registada em documento de 30 de Julho de 1208, passado em Zamora, porque da autoria do seu bispo e do deão do respectivo cabido, na qualidade de juízes apostólicos (Estudos..., p. 108-111, doc. 12). Esta posição do abade está corroborada pelo registo da sua atitude de denúncia da falsidade dos selos apostos no instrumento de renúncia do abade Julião ao seu mosteiro (Estudos..., p. 113, doc. 14). Sendo assim, tem de concluir-se que o abade mudou de opinião e de campo entre o ano de 1205 e o de 1208, pelo menos; (para o primeiro, ver Estudos ..., p. 104, doc. 7).

${ }^{14}$ Isto mesmo afirma o bispo de Coimbra em documento não datado, mas que se tem de situar pelo final do ano de 1205, por certo no seu último trimestre. Cfr. Marcelino Rodrigues Pereira, "O latim de alguns documentos da Sé de Coimbra (1086-1210)", in Revista Portuguesa de História, V, p. 379-380, doc. IV. Este autor propõe o ano de 1206, tendo em vista a redacção do documento episcopal, enquanto nós consideramos antes a notícia que ele veicula, isto é, a presença do abade de Lorvão no mosteiro de Pedroso e o tempo da sua entrada aí. Esta teria sido ou mesmo anterior ou praticamente simultânea à entrada das freiras 
no ano de $1205^{15}$. Pela nossa parte, já tentámos encontrar a sua pista no cartório dessa instituição. Em vão. Percorremos a documentação até 1247 e, em nossa opinião, talvez que um monge, de nome Julião, que testemunha actos em 1243, 1244 e 1245 se possa identificar com o último abade de Lorvão. Sobre os monges, alguns deles acabaram por sair de Pedroso, «ad monasteria in quibus religionis habitum susceperant et professionem fecerunt monachalem». Mas quanto a esses, não temos qualquer pista para os seguirmos, nem, muito menos, uma indicação, mínima que seja, desses mosteiros onde terão professado. Por isso, perguntamo-nos se, acaso, se passou, neste momento, algo de semelhante ao que o papa viria a recomendar, em 1210, no final da questão ${ }^{16}$, isto é, que a sua reinserção noutros mosteiros fosse feita, um a um, por diversas casas monásticas, em vez de numa única, em grupo, ainda que pouco numeroso.

Mesmo aceitando a pequenez da comunidade lorbanense, ainda assim há que admitir outros destinos para os seus egressos ${ }^{17}$, de que não é de excluir a saída para o estrangeiro, tanto mais que as queixas sequentes à retirada de Lorvão se fizeram pela cúria pontifícia, mas também por Zamora e Santiago [de Compostela], como dizem os documentos que dão conta do final do processo $^{18}$. Claro que a causa não exigia necessariamente a presença de qualquer monge, mas também nada a nega. Ora, saídos do reino, em busca de justiça ou, pelo menos, de aliados, a por lá terem ficado terá sido um simples passo.

em Lorvão. Quanto aos mosteiros onde se teriam acolhido, apenas é citado o de Pedroso, nenhum mais. Cfr. Bernardo Vasconcelos e Sousa (Dir.), Isabel Castro Pina, Maria Fernanda Andrade e Maria Leonor Ferraz de Oliveira Silva Santos, Ordens religiosas em Portugal. Das origens a Trento - Guia histórico. Lisboa: Livros Horizonte, 2005, p. 117, onde se cita também o de Pendorada.

${ }^{15}$ Admitindo-se que as freiras fizeram a sua entrada em Lorvão na véspera de Natal de 1205, o mosteiro já teria que estar vago dos seus anteriores moradores. Logo, estes teriam que ter já nova morada e o mosteiro de Pedroso era a do seu abade e, talvez, também a de alguns dos seus monges.

${ }^{16} \mathrm{Na}$ bula Causam que vertebatur, de 15 de Novembro de 1210 (Bulário..., p. 286-287, n. $\left.{ }^{\circ} 148\right)$, manda que os monges fossem integrados, «um a um, em mosteiros bem ordenados», como veremos.

17 À semelhança do que, no séc. XIX, aconteceu a muitos dos exclaustrados pelo Decreto de 28-30 de Maio de 1834: refazerem carreiras, ordenando-se (no caso de o não serem), entrarem no clero paroquial, seguirem profissões no século.

${ }^{18}$ Estudos..., p. 117-120, dos. 17 e 18. 
Aliás, a crermos nas notícias de Fr. Leão de São Tomás ${ }^{19}$, o cronista dos beneditinos portugueses, que escreveu no séc. XVII, um desses egressos de Lorvão terá sido um tal Fr. Ricardo, que saiu do reino e rumou até Itália, tendo-se ficado por Monte Cassino, berço da sua Ordem, acolhido à sombra protectora do túmulo e da aura do fundador e protector dos beneditinos. Ainda segundo o cronista, de Monte Cassino, Fr. Ricardo terá escrito uma carta a um seu ex-confrade de Lorvão, agora no mosteiro de Pedroso, cujo texto o mesmo Fr. Leão de São Tomás nos transmite ${ }^{20}$. A sua leitura deixa perceber alguns problemas, alguns dos quais já apontados por outros autores, coevos, de que o mais importante é, parece-nos, o problema da sua data, no que ao ano diz respeito (1201). Cremos que o seu erro é demasiado flagrante para sair da pena de um homem que se diz ter feito parte de um grupo que sofreu todo um processo como foi o da expulsão dos monges de Lorvão, do seu mosteiro. Portanto, cremos que sem ficar de excluir a existência de um monge que, mais do que ele mesmo, vale como símbolo de outros mais que, expulsos de Lorvão, podem ter ficado errantes pelos caminhos do reino e da cristandade, a maioria dos egressos de Lorvão terá permanecido no reino, em diversas situações, de que uma possível terá sido o ingresso em outras casas monásticas. Mas perde-se-lhes o rasto, no desconhecimento dos seus destinos.

Por outra via, cremos que o desenrolar da questão indicaria que os monges, isto é, uma sua parte, não se afastassem da região. Diremos mesmo que os partidários da entrega do mosteiro haviam de achar acolhimento no seio da corte régia ou em ambiente afim. Notando que o documento do bispo de Lamego que tornou público que o abade e monges de Lorvão receberam 500 áureos da rainha $\mathrm{D}$. Teresa para as despesas com o processo e declararam não querer reingressar no mosteiro, renunciando aos documentos alcançados do papa e do arcebispo de Compostela, juiz apostólico na causa, contou com a presença do chantre do Coimbra, do arcediago Mendo Martins, do mestre (escola), do acólito Estêvão, e dos priores das igrejas de Santiago (Pedro Rodrigues) e de São Bartolomeu (Frutuoso) ${ }^{21}$, mais convicta ficamos

${ }^{19}$ Beneditina Lusitana. Introdução e notas críticas de José Mattoso. Ed. fac-similada. I, Lisboa: Imprensa Nacional - Casa da Moeda, 1974, p. 338-348.

${ }^{20}$ Ibidem, p. 342-343.

${ }^{21}$ Esta igreja pertencia ao mosteiro desde 957; cfr. Aires Nascimento, ob. cit., p. 147. 
do apoio conimbricense (ou pelo menos do de algum do clero da cidade) que a facção pró-entrega do mosteiro granjeava ${ }^{22}$. Aliás, esta atitude está de acordo com uma outra, de 1206, que indica o mesmo sentido: a presença de muitos religiosos da igreja de Coimbra, entre os quais os detentores das dignidades do cabido, confirmando e subscrevendo o documento do bispo de Coimbra, pelo qual ele concedia o mosteiro à rainha $\mathrm{D}$. Teresa, depois de aí ter introduzido monjas da Ordem de S. Bento, por ser a única maneira de salvar o mosteiro ${ }^{23}$. Assim, e apesar das dúvidas, parece ficar claro o apoio do clero de Coimbra à atitude do seu bispo, em relação ao mosteiro de Lorvão. Se era genuíno e justo, isso já é outra questão, para a qual não temos resposta.

No final da contenda, ao dar conta das muitas diligências que fizera por ordem do seu metropolita, o arcebispo de Compostela, simultaneamente juiz apostólico, o bispo de Lamego informa de que, no seu cumprimento da ordenação papal, depois de ter recebido a renúncia e a resignação do abade e dos monges, concedera cartas (de recomendação) àqueles monges que fossem recebidos «noutros mosteiros, bem ordenados». Mais uma passagem que sempre nos surpreendeu e não deixa de nos intrigar. Em primeiro lugar, a atitude do bispo é selectiva: apenas se dirigia àqueles que fossem recebidos noutros mosteiros. Mas quais seriam? Uma resposta parece óbvia, ao nosso olhar: aqueles que estivessem isentos do rótulo de vida dissoluta. Mesmo assim, não nos colocamos numa perspectiva maniqueísta, escolhendo entre coniventes e resistentes; uns e outros ofereciam a capacidade de poder ser considerados rectos ou impuros. Por isso, entendemos que a declaração do bispo permite pensar que nem todos seriam recebidos noutros mosteiros. Porquê? Colherá a mesma razão que considerámos anteriormente? Isto é, estavam, à partida, afastados aqueles a quem pudesse ser colocado o labéu de dissoluto? Mas, ainda assim, o que considerar por dissoluto, na circunstância? No meio de tantas dúvidas, não pode deixar de atender-se a uma passagem da bula Causam que vertebatur, a última sobre o processo. Aí se diz que «os monges colocados, um a um, noutros mosteiros façam penitência dos seus pecados e que a liberdade eclesiástica não seja escravizada pela

\footnotetext{
${ }^{22}$ Estudos..., p. 116-117, doc. 16.

${ }^{23}$ Ibidem, p. 105, doc. 8 .
} 
insolência [do poder] secular» ${ }^{24}$, o que pode permitir a hipótese de algum auxílio deste a uma conduta menos correcta dos monges de Lorvão ou, tão-só, ser sinal da ingerência do poder secular (régio) na questão de Lorvão.

Mas o processo da mudança de ocupantes do mosteiro de Lorvão, no início do séc. XIII, não deixa de nos surpreender. Em Outubro de 1206, o abade de Lorvão era claramente acusado, em bula papal ${ }^{25}$, de «ter resignado nas mãos do rei, sem consenso e vontade do seu mosteiro». Porém, em breve a sua atitude mudou, pois em documento de 30 de Julho de 1208, passado em Zamora pelo bispo da cidade e dirigido ao papa, dando conta do andamento do processo, já se dá conta da reacção dos monges e de «Julião, que se dizia abade de Lorvão». E, a partir daí, até ao desenlace final, ele não deixou de estar presente, sublinhando-se, até, a comunhão de sentimentos e atitudes, entre ele e os seus monges; perante a sentença papal, final, «uno ore, una voce», declararam não querer retornar ao seu mosteiro, nas condições impostas pelos delegados apostólicos, mas preferirem resigná-lo.

Onde começavam e onde acabavam os contornos da ambiguidade das atitudes desta figura? Talvez que na citada bula Causam que vertebatur, de 15 de Novembro de 1210, e dirigida ao arcebispo de Compostela se ache alguma pista: «prefatos abbatem et monachos per vim et metum fuisse cohactus monasterium de Lorbano deserere», fez escrever o papa, numa altura do processo em que estaria muito bem esclarecido, bem como já não teria ilusões acerca da figura do rei de Portugal, dos seus conselheiros e das suas atitudes. Mas onde se alterou o espírito e o sentir do abade de Lorvão? Onde ganhou coragem para mudar a sua atitude de receio e transformar «a força e o medo» que o podem ter coagido a agir em contradição com a sua própria condição? Se ele ingressou em Pedroso, após a resignação do seu mosteiro, em 1205, teria esta comunidade religiosa alguma responsabilidade na sua transformação? Acaso, aí achou força e apoio para assumir os seus deveres de abade e para renegar a atitude de sujeição e conivência de que dera prova, ao renunciar ao seu mosteiro? Bom seria acharmos uma pista para tanta questão, mas nada conhecemos que nos possa esclarecer.

\footnotetext{
${ }^{24}$ Ibidem, p. 287.

${ }_{25}^{25}$ Si karissimus in Christo, de 1206, Outubro, 24, Latrão. Estudos..., p. 106, doc. 9, dirigida ao bispo e deão de Zamora e ao abade de Moreruela.
} 
Talvez também que os conselheiros do abade, por cautela, tenham preferido ficar na sombra.

Ora, a abordagem que hoje apresentamos, mais focada que a que havíamos realizado em 1980, vem, afinal, reforçar aquela faceta do rei D. Sancho I, de interventor em matérias eclesiásticas, mesmo com o recurso à violência, em data em que se desenrolavam outros processos com o clero, nomeadamente com o bispo de Coimbra ${ }^{26}$.

Porém, em bom rigor, nada do que afirmamos toca no ponto essencial da questão de Lorvão no final do séc. XIII, os motivos da retirada dos monges.

Nos nossos estudos, sempre temos defendido o papel de vítimas que os monges de Lorvão nos parecem ter sido, nas mãos do rei de Portugal ${ }^{27}$, do bispo de Coimbra e da ex-rainha de Leão.

Porém, Aires Nascimento, no importante estudo que nos tem vindo a servir de referência ${ }^{28}$, desenvolve toda uma construção que centra o problema numa «comunidade rebelde» ${ }^{29}$, pouco aberta à inovação, que dificultou «a transição para o novo regime regular» (leia-se o proposto pela regra beneditina $)^{30}$. Baseia-se na «conservação de livros tradicionais», através «de cópias» ${ }^{31}$, na «solidariedade» perceptível entre o abade e a comunidade, na designação desta por «collegium», «collatio», «congregatio»» ${ }^{32}$, no antagonismo entre a comunidade lorbanense e os bispos de Coimbra, cuja memória ficou exarada em documento do final do séc. XII ${ }^{33}$.

${ }^{26}$ De recordar que no final desse mesmo ano de 1210 se agravaram as relações entre o rei e o bispo de Coimbra, de que dão prova evidente as bulas Si diligenter attenderes, Licet veberabilis e Vehementer nos zelus, todas de início de 1211 (Bulário..., p. 295-301, nºs. 154,155 e 156), sendo certo que acabara de sair de uma outra contenda, com o bispo do Porto.

${ }^{27}$ Com este, já os monges teriam tido uma outra questão, como é referiro no relatório do bispo de Zamora e do seu deão, em 30 de Julho de 1208 (cfr. Estudos..., p. 84 e 111, doc. 12).

${ }^{28}$ Citado supra, nota 3.

${ }^{29}$ Ob. cit., p. 107.

${ }^{30}$ Notamos que esta interpretação aponta para a persistência mais longa que normalmente se indica, e cronologicamente mais consentânea, da tradição peninsular, em termos de vida monástica. Pensamos mesmo que a posição indicada exige um aprofundamento das pistas que propõe, até tendo em vista as novas manifestações no panorama do monaquismo português do séc. XIII.

${ }^{31}$ Aires Nascimento, ob. cit., p. 107.

${ }^{32}$ Ob. cit., p. 107.

${ }^{33}$ Se esta é a queixa dos monges acerca dos bispos, perguntamo-nos se estes não tinham outros agravos daqueles, além do não pagamento dos direitos episcopais. Questionamo-nos 
Pela nossa parte, pretendemos, antes, chamar a atenção para alguns aspectos que ora se nos mostram com mais vigor e fazem acrescer as nossas dúvidas.

São, eles, a questão de Pedroso e a profissão monástica dos monges saídos de Lorvão. Porquê a escolha deste mosteiro? Se admitirmos que também, nessa opção, não houve qualquer coação sobre os monges e que o abade de Lorvão e os seus monges o escolheram ou aceitaram de livre vontade, que afinidades teriam com ele? Ou, bem ao contrário, que mais valia apresentaria esta casa monástica, aos olhos do bispo de Coimbra, que a escolheu ou aceitou para acolhimento de monges de vida dissoluta e delapidadores de bens?

$\mathrm{Na}$ verdade, não sabemos (e duvidamos que se saiba). Mas cremos que qualquer tentativa de resposta tem que equacionar as questões que formulámos anteriormente. De acordo com elas, ou o mosteiro de Pedroso era, ainda, um certo representante da tradição ${ }^{34}$ (a ponto de os monges

também se o sentimento era geral e se não havia solidariedades com o bispo e o que é que estas podiam significar. Por exemplo: que leitura deve fazer-se da presença dos monges de Lorvão entre os de nove mosteiros (todos das Beiras, à excepção deste mesmo) que se dirigiram ao papa Inocêncio II sobre as atitudes do arcebispo D. João Peculiar contra o bispo de Coimbra, D. Bernardo? Cfr. Livro Preto da Sé de Coimbra. Edição crítica. Texto integral. Director e Coordenador Editorial: Manuel Augusto Rodrigues. Director Científico: Cónego Avelino de Jesus da Costa. Coimbra: Arquivo da Universidade, 1999, p. 860-861, n. ${ }^{\circ} 636$ (doravante citado por LP.). Por contraponto, refira-se que nas citadas queixas dos monges de Lorvão sobre os bispos de Coimbra, se encontram referências sobre este bispo; cfr. Rui de Azevedo, O mosteiro de Lorvão na Reconquista cristã. Separata do Arquivo Histórico de Portugal. Lisboa, 1933, p. 60-61, n. ${ }^{\circ}$ XXI. Por completude, pois que pode ter sentido diverso de tudo isto, não passando efectivamente do que formalmente é, acrescente-se o juramento de obediência do abade Salvador, à Sé de Coimbra, na pessoa do mesmo bispo Bernardo, que ficou exarado em LP. (p. 107, n. ${ }^{\circ}$ 62) e que deve situar-se por 1143-1146 (cfr. Aires Nascimento, ob. cit., p. 99-100, n. 51). Registada fosse a que título fosse, pelos responsáveis da Sé de Coimbra, fica sempre a dúvida, de sentido positivo ou negativo, do valor que davam à memória desse acto.

${ }^{34}$ Segundo José Mattoso, o mosteiro de Pedroso terá sido um dos últimos a adoptar os costumes beneditinos (Le monachisme ibérique et Cluny: les monastères du diocese de Porto de l'an mille à 1200. Louvain: Publications Universitaires de Louvain, 1968 [trad. Port.: O monaquismo ibérico e Cluny. Obras Completas, vol. 12, Lisboa: Círculo de Leitores, 2002], p. 126-129. De notar, contudo, a opinião de A. Linage Conde, Los orígenes del monacato benedictino en la Península Ibérica. II, La difusión de la "regula benedicti", León: Centro de Estúdios e Investigación "San Isidoro"/CISC, 1973, p. 745). Tenha-se ainda presente que foi neste mosteiro que Maria José Azevedo Santos encontrou a prova documental mais tardia "do uso da escrita visigótica, acentuadamente de transição para a carolina", com data de 1172, 
eventualmente o terem escolhido) ou já um local de sólida adesão a novas correntes (no caso, a beneditina) que a hierarquia queria que fosse (e entendia que seria) contagiante aos «rebeldes» de Lorvão ${ }^{35}$. Certo, nos fica, que, perante uma situação grave, e agravada na circunstância, que levava o bispo de Coimbra a escolher, ou aceitar, um mosteiro para acolhimento dos monges de Lorvão, não era grande a sua possibilidade de escolha. Ao longo do séc. XII, assinala-se a presença de mosteiros na parte sul da diocese de Coimbra, como revelámos recentemente ${ }^{36}$, e que, necessariamente, estavam ligados à tradição peninsular, mas os aspectos da sua vida desconhecem-se totalmente (incluindo as relações com o bispo diocesano), e regista-se a efervescência que se vivia noutros, que não sendo em território da diocese, se achavam sob a alçada do bispo de Coimbra $^{37}$. E que significado tem a presença do mosteiro de Lorvão entre os nove que, entre 1139-1143, se dirigiram ao papa, denunciando os actos condenáveis do arcebispo de Braga, em Coimbra, e pedindo protecção para o seu bispo, então D. Bernardo? ${ }^{38}$

enquanto foi em Lorvão e relativamente ao ano de 1168 que se confrontou com a presença da "última carta completa e original no mesmo tipo de letra" (Da visigótica à carolina. A escrita em Portugal de 882 a 1172 (aspectos técnicos e culturais), Lisboa: Fundação Calouste Gulbenkian - Junta Nacional de Investigação Científica e Tecnológica, 1994, p. 200). Acaso se deverão aproximar estes aspectos de tudo quanto se terá passado no mosteiro de Lorvão?

${ }^{35}$ Isto, sem questionarmos a informação do documento de 29 de Agosto de 1108 (LP., p. 711-713, n. ${ }^{\circ} 533$ ), que indica a compra de $1 / 8$ do mosteiro de Pedroso, pelo bispo D. Maurício, e o percurso histórico desse acto.

${ }^{36}$ O arcediagado de Penela na Idade Média. Algumas notas. Separata de Revista do Centro de História da Sociedade e da Cultura da Universidade de Coimbra, 8 (2008), p. 97-143. Aí assinalamos os mosteiros de Murta (c. Alvaiázere), Alge (c. Figueiró dos Vinhos), e Pêra (c. Castanheira de Pêra), todos existentes ainda no início do séc. XIII, mas desaparecidos depois, sem que se conheça a sua vida ou qualquer processo da sua morte. Estes mosteiros não colhem qualquer referência na obra Semente em boa terra. Raizes do Cristianismo na Diocese de Coimbra. Coimbra: Gráfica de Coimbra, 2000, especialmente a p. 55-57.

${ }^{37}$ Referimo-nos aos mosteiros em território da diocese de Viseu, que viveram, nesse século, a sua passagem a Cister. Cfr. Maria Alegria Marques, «A introdução da Ordem de Cister em Portugal», in Estudos..., p. 29-73.

${ }^{38}$ Livro Preto da Sé de Coimbra. Edição citada, p. 860-861, n. ${ }^{\circ}$ 636. Os restantes mosteiros são: São João de Tarouca, São Pedro das Águias, São Nicolau de Bagaúste, Santa Maria de Cárquere, São Miguel de Paiva, São Pedro de Tonda, Santiago de Sever, Santa Maria de Figueiredo. De notar que, dentre aqueles que sobreviveram, a maioria se ligou à observância cisterciense (à excepção de Cárquere, que se afirmou crúzio, e São Miguel de 
E, ao haver notícia de monges de Lorvão que, agora (1205), colocados perante factos que se adivinhavam irremovíveis, se vergavam, finalmente, à aceitação de uma nova orientação espiritual, patente na indicação de que fizeram profissão monástica nos mosteiros em que entraram, perguntamo-nos que monges eram esses e que profissão era essa. Ou, questionamo-nos, se, antes, não estaremos perante alguns daqueles homens que sempre gravitaram à volta dos mosteiros, mas não eram monges professos e que, agora, abandonados e despojados, assim procuravam elos que os vinculassem e garantissem numa instituição, situação que não deixaria de levantar outros problemas, como é óbvio.

O desmantelamento da comunidade, após a retirada para Pedroso, sugere-nos também alguma reflexão. A sua justificação tem que procurar-se quer em factores endógenos, de que a contumácia dos monges em perseverarem no seu modus vivendi seria o principal e aconselharia a dispersão, quer em factores exógenos, de logística tão-só (ou outros), onde não faltaria a intenção do bispo de Coimbra e a anuência do do Porto ${ }^{39}$. Mas numa intenção dirigida a quê e numa anuência motivada por quê?

3. Como corolário de todos estes problemas, um outro se impõe: qual o papel de D. Teresa, em todo este processo da expulsão dos monges e da introdução de monjas no mosteiro de Lorvão? Temos defendido que, regressada do reino onde reinou, Leão, D. Teresa teria buscado um lugar para recolhimento. Propusemos que o tenha feito à semelhança do que estava em uso em Castela, através do mosteiro de Las Huelgas. Com a acção do

Paiva, que, provavelmente, veio a ser a ermida premonstratense de Santa Maria de Paiva). Perguntamo-nos que elo tinha o mosteiro de Lorvão com todos estes, em 1139-1143, ou se esta associação foi meramente esporádica e circunstancial.

${ }^{39}$ Curiosamente, o bispo do Porto surge mencionado na questão em 1206, por ter sido nomeado delegado apostólico à questão (Estudos..., p. 107-108, docs. 10 e 11), em lugar do bispo de Lisboa, cuja presença fora contestada pelos monges de Lorvão reclamantes acerca da situação. Aliás, no documento de 28 de Dezembro de 1206, em que se tornava público e certificava que por cuidadosa investigação fora considerada legítima a concessão do mosteiro à rainha $\mathrm{D}$. Teresa e a introdução de monjas, nele, lê-se que estiveram presentes, ao acto, o deão do Porto, o prior de Cedofeita e o capelão do bispo do Porto. Talvez sintomaticamente, apesar de o bispo do Porto ser considerado juiz delegado pelo papa (Estudos..., p. 107, doc. 10), não conhecemos qualquer nomeação, nem ele voltou a aparecer ou, sequer, a ser citado em qualquer fase do processo. Curiosamente, há aqui alguma simultaneidade com as desavenças do bispo do Porto com o rei; dever-se-á a isso esta fugaz presença nesta contenda? 
pai e a ajuda do bispo de Coimbra, os monges de Lorvão foram forçados a ceder-lhe a sua casa.

Por sua vez, Aires Nascimento propõe uma interpretação algo diferente: não teria havido uma primeira intenção de $\mathrm{D}$. Teresa, mas antes um aproveitamento da situação gerada à volta de Lorvão. Pela nossa parte, atenta no desenrolar dos factos que envolveram a ex-rainha de Leão, seu pai e suas irmãs, continuamos a perfilhar a mesma opinião. Num momento, ruíra o seu mundo. Fora a sua separação forçada, em 1194, o seu regresso a Portugal, com a infanta D. Dulce, o casamento de seu ex-marido, o rei de Leão, com Berengária de Castela (1197); a morte da rainha de Portugal, Dulce, sua mãe, em 1198, a orfandade de suas irmãs, Mafalda (a que menos cuidados lhe daria, pois que entregue aos cuidados de uma ama que a adaptou de corpo e alma), Branca e Berengária, de tenra idade; os novos amores de seu pai. Tudo pesaria numa decisão de D. Teresa, em buscar um refúgio das amarguras do mundo; aliás, a exemplo do que fizera também sua tia e sogra, D. Urraca Henriques, quando se viu separada de seu marido, Fernando II, também ele rei de Leão. Além de que, não havendo qualquer intenção de $\mathrm{D}$. Teresa no processo, como interpretar o facto de a rainha ter dado 500 áureos, aos monges de Lorvão, para pagamento das despesas do litígio e em troca de os monges renunciarem ao seu mosteiro? ${ }^{40}$ Ainda que se possa pensar que esta obrigação escondia os verdadeiros agentes da acção, também nos parece demasiado pesada e até comprometedora para quem não tivesse qualquer responsabilidade nos actos e se tivesse limitado a receber um bem, ainda que ele fosse o secular mosteiro de Lorvão.

No final, como saldo, talvez que o segredo da salvação do mosteiro de Lorvão tenha residido em tudo isto ${ }^{41}$.

4. Questionado o destino dos homens de Lorvão, há outras perguntas que se impõem: qual foi o destino do património do mosteiro de Lorvão? E todo

${ }^{40}$ Estudos..., p. 116-120, docs. 16, 17 e 18.

${ }^{41}$ Sobretudo se pensarmos que é possível admitir que a causa do desaparecimento do mosteiro da Vacariça, muito próximo do de Lorvão, e entre os quais se contam tantas afinidades, tenha sido a teimosia dos seus monges em não aceitarem a nova ordem espiritual que se impunha na Cristandade, o beneditismo. 
ele teve a mesma sorte? A resposta mais óbvia a estas questões passa pela consideração do percurso dos bens imóveis do mosteiro. E aí, como também já demonstrámos, não se percebe qualquer quebra no imenso património que a instituição já detinha. Não obstante, registamos que os documentos papais são persistentes em considerar a má gestão dos monges, no espiritual e no temporal ${ }^{42}$. Mas não pode esquecer-se que é o próprio pontífice a considerar a possibilidade de a casa vir a acolher 40 monjas. Haveria, pois, capacidade material para prover ao seu sustento. Donde, fica a dúvida da dissipação atribuída aos monges. E pela análise do cartório do mosteiro chegado até nós, não há, em rigor, uma visão tão catastrófica da situação desse mesmo património. Portanto, perguntamos: o que conhecemos, hoje, do cartório do mosteiro? Perderam-se muitos documentos? Destruíram-se uns quantos? (situação não muito aceitável, pois haveria todo o interesse em fazer prova, à posteridade, dessa má gestão dos monges de Lorvão).

No entanto, ainda no estudo que vimos seguindo, Aires Nascimento coloca também o problema da vida económica do mosteiro, afirmando que ela «estava em ruptura no início do séc. XIII, apesar de compras havidas e de doações recebidas $\rangle^{43}$.

Ora, pelo que já escrevemos, repetidamente, e ainda mesmo, agora, neste aspecto, de forma alguma podemos seguir o ilustre Professor. $\mathrm{O}$ arrendamento que invoca, não passava de vulgar forma de gestão do património fundiário; nos penhores que indica, o mosteiro apresentava maior capacidade no seu resgate que necessidade na hipoteca que fez. Por isso, mantemos, hoje, a opinião de que, nos últimos anos de ocupação masculina, o mosteiro de Lorvão se mostrou com capacidade económica desafogada, como o provam as muitas compras que fez e os montantes que envolveram, bem como as doações de que continuou sendo alvo ${ }^{44}$, ou, maxime, a capacidade que

${ }^{42}$ Atente-se nesta passagem da já citada bula Causam que vertebatur, passada em Latrão, a 15 de Novembro de 1210, no final do conflito: «predictum monasterium per eosdem abbatem et monachos multis et magnis criminibus irretios in spiritualibus et temporalibus esse collapsum».

${ }^{43}$ Ob. cit., p. 150.

${ }^{44}$ Estudos..., p. 80-82. 
apresentava, no final da contenda, de poder acolher 40 monjas, segundo reconhecia o próprio papa ${ }^{45}$, como referimos acima.

Quanto aos prejuízos espirituais invocados, quais foram eles, que tanto prejudicaram a casa de Lorvão? Seria essa persistente contumácia, em não acatar as novas orientações em matéria de vida monacal, que os bispos de Coimbra tanto gostariam de ver implantadas no cenóbio de Lorvão e por que tanto porfiaram, desde o início do séc. XII, de seguida à restauração do mosteiro, em 1116? Sem resposta, no momento, a questão fica em aberto, até novas e mais argutas reflexões. E entendemos que ela não pode centrar-se apenas em Lorvão e nos seus monges. O que deixamos escrito acerca do caminho, ou de um dos caminhos, que lhe foram propostos obriga a equacionar também o momento que se viveria no mosteiro de Pedroso ${ }^{46}$.

5. Porém, valha a verdade, assinala-se uma parcela valiosíssima do imenso património do mosteiro de Lorvão que não terá sofrido quebra ou, pelo menos, quebra assinalável. Referimo-nos ao seu formidável espólio em manuscritos, litúrgicos ou não. A riqueza que ele era e representava não foi beliscada. Por um lado, os monges souberam preservá-lo, nesse vendaval em que meteram o seu mosteiro ou em que foram apanhados ${ }^{47}$; por outro, as monjas souberam apreciá-lo, prova de que eram suficientemente ilustradas, a ponto de o perceberem e valorizarem, ou souberam rodear-se de homens, directores espirituais, que bem os conheciam, apreciavam e souberam preservar.

Ao tema que hoje nos congrega aqui - Continuidades e rupturas na cultura unducentista do Mosteiro Laurbanense - considere-se que, tanto os mosteiros femininos, como os masculinos, necessitavam de livros da mesma

${ }^{45}$ E note-se que não há referência, por este tempo, à concessão de bens por D. Teresa. Torna-se também interessante atender-se aos principais bens comprados, por D. Teresa, para o mosteiro, entre 1206 e 1211. De 10 actos conhecidos, 7 relacionam-se com compras de 8 olivais (cfr. Estudos..., p. 171-172).

${ }^{46}$ Para o itinerário do estudo deste mosteiro siga-se Bernardo Vasconcelos e Sousa (Dir.), Isabel Castro Pina, Maria Fernanda Andrade e Maria Leonor Ferraz de Oliveira Silva Santos, ob. cit., p. 59.

${ }^{47}$ Embora não possamos afirmar o que representa o que nos chegou do seu tempo e, por isso, responder a uma outra das questões colocadas para este Seminário: o que levaram os monges consigo, para além da memória e da sombra do seu mosteiro? 
natureza, de vivência dos ofícios litúrgicos e do fortalecimento espiritual. Neste campo, obras como o Liber usuum de Cister, as constituições, os comentários à regra de S. Bento, o Comentário de Santo Agostinho aos Salmos, o Comentário ao Cântico dos cânticos, de São Bernardo, os livros litúrgicos (Leccionário, Antifonário), o Martirológio, os livros canónicos, os Moralia ou Expositio in Liberum $\mathrm{Job}^{48}$, tanto diziam a monges, como a monjas. Já o mesmo não se dirá do Apocalipse ou do Passionário Hispânico, obras de um tempo e de uma cultura hispânica antiga, que já pouco diriam às monjas. Ou do Livro das Aves, das cópias do Vocabularium de Papias, ou de Hugo de São Vítor ou de Hugo de Folieto, pelo seu carácter específico, mais dirigido a interesses de natureza científica e intelectual, embora sem descuido dos aspectos que diziam respeito à espiritualidade ${ }^{49}$.

Por isso, entendemos que mais que procurar permanências, haverá de perscrutar a inovação: o que é que as monjas de Lorvão trouxeram, de novo, a Lorvão? Aceitando a proveniência estrangeira da sua primeira abadessa e tendo em conta os muitos contactos da sua protectora, a rainha D. Teresa, com o reino de Leão, que novidades apresentou o seu tempo, em termos de livros na biblioteca do mosteiro? E, se sim, pode estabelecer-se alguma relação com Leão? E que nos mostra o espólio do mosteiro, chegado até nós, relativamente ao conhecimento da espiritualidade das místicas cistercienses da época ${ }^{50}$

Tudo questões que já pertencem a um outro campo, de um outro mundo, em que, manifestamente, não nos movimentamos. Mas sempre percebemos que os manuscritos lorbanenses ajudavam a uma certa espiritualidade que procuravam pelo menos algumas das mulheres entradas em Lorvão nesse longínquo Natal de 1205 e, definitivamente, no primeiro semestre do ano de 1211, há quase 800 anos.

${ }^{48}$ Dicionário da Literatura Medieval Portuguesa Galega e Portuguesa. Org. e coord. de Giulia Lanciani e Giuseppe Tavani. Lisboa: Caminho, 1993, s.v. Mosteiros.

${ }^{49}$ Admitindo, todavia, o interesse genérico que estas obras podiam suscitar em monjas que as viam pela primeira vez e que nelas podiam descobrir alguma emoção intelectual.

${ }^{50}$ Sobre a temática da cultura literária e da espiritualidade entre as monjas cistercienses na Idade Média, ver Les moniales cisterciennes. Dir. Jean de la Croix Bouton. IV, Abbaye de Notre Dame d'Aiguebelle: Commission pour l'Histoire de l'Ordre de Cîteaux, 1989, p. $69-90$ e 101-138. 